\title{
Siirt İl Merkezindeki Tüketicilerin Organik Ürün Tüketim Tercihleri ve Tercihlerini Etkileyen Faktörlerin Belirlenmesi
}

\section{Oğuzhan ÇAM'(i), Ersin KARAKAYA ${ }^{* 2}$}

\author{
' Kurtalan Meslek Yüksekokulu Dıș Ticaret Bölümü Dıș Ticaret Programı, Kurtalan/Siirt \\ ${ }^{2}$ Bingöl Üniversitesi Ziraat Fakültesi Tarım Ekonomisi Bölümü, Bingöl
}

Öz: Hem insan sağlığı hem de doğanın korunması için organik beslenme, organik ürün yetiștirme ve organik tarım yapma önemle dikkat edilmesi gereken bir durumdur. Bu çalșma, Siirt il merkezindeki tüketicilerin organik ürünlere yönelik tercihlerini ve organik ürünleri tercih etmelerinde etkili olan faktörleri belirlemek amacıyla yapılmıștır. Araștırma materyali olarak, Siirt ili kent merkezindeki 27 I birey ile 2017 yılında yapılan anket çalıșmasından derlenen yatay kesit verileri kullanılmıștır. Araștırma bulgularına göre; tüketicilerin \%63'ünün erkek, \%7l'inin bekâr olduğu, tüketicilerin yaș ortalamasının 34.2 ve aylık gelirlerinin ise $1200 \mathrm{TL}$ olduğu belirlenmiștir. Organik ürünler hakkında bilgi sahibi olan tüketici oranı \%7।.8 olarak bulunurken, bilgi kaynağı olarak \%46.8 ile internet ilk sırada yer almıștır. Tüketicilerin \%84.3'ü organik ürün tükettiğini ifade etmiș ve tüketilen organik ürünler arasında \%62.2 ile yaș sebze ve meyve ilk tercih olarak belirlenmiștir. Sonuç olarak; organik ürünlerin güvenli olması ve organik ürünlerinin sağlığa zararlı olmaması, gibi faktörlerin organik ürün tüketim tercihini etkileyen en önemli faktörler olduğu saptanmıștır. Kontrol ve sertifikasyon ile ilgili olarak tüketici bilincinin olușmaması, reklam faaliyetlerinin yetersiz kalması ve pazarlama önemli sorunlar arasında yer almaktadır. Pazarlama marjııın tüketici lehine olması, organik ürün satıș yerinin güvenilirliği ve temizliğine yönelik yapılacak çalıșmaların organik ürünlerin tüketimini arttıracağı sonucuna varıımıștır.

Anahtar Kelimeler: Siirt, aylık gelir, yaș sebze ve meyve, pazarlama

\section{Determination of Consumption Preferences of Organic Product and Factors Affecting Consumption Preferences of Consumers in Siirt Province}

Abstract: Organic nutrition, organic cropping and organic farming are all important considerations for both human health and the protection of nature. This study was conducted to determine the preferences of consumers for organic products and the factors that are effective in choosing organic products in Siirt province center. Horizontal section data compiled from the questionnaire survey made with $27 \mathrm{I}$ individuals were used as the research material in Siirt city center in 2017. According to results of the study, $63 \%$ of the consumers were male, $71 \%$ were single, the average age of the consumers was 34.2 and monthly income was I,200 TL. The consumer ratio, which has knowledge about organic products, was found as $71.8 \%$ while internet was the first information source with as $46.8 \% .84 .3 \%$ of the consumers stated that they consumed organic products and $62.2 \%$ of the consumed organic products were fresh vegetables and fruits as the first choice. As a result; it is determined that the factors such as "organic products are safe" and "organic products are not harmful for health" are the most important factors affecting organic product consumption preference. The lack of consumer awareness about control and certification, the inadequacy of advertising activities and marketing are among the major problems. The marketing margin is favored by the consumer, and the work to be done for the reliability and cleanliness of the organic product sales place is the result of increasing the consumption of organic products.

Keywords: Siirt, monthly income, fresh vegetables and fruits, marketing

\section{GiRiș}

Doğal sistemleri değiștirmek yerine doğa ile uyumlu bir sistemin ortaya konulmasını benimseyen organik tarım, son zamanlarda küresel boyutta artan bir ivme kazanmıștır. Uluslararası Organik Tarım Hareketleri Federasyonu (IFOAM) ve FIBL Araștırma Enstitüsü 2017 verilerine göre Dünya'da 2.4 milyon üretici tarafından, 50.9 milyon hektar alanda organik tarım yapıldığı belirlenmiștir. Dünyada, toplam tarım alanlarının yaklașık \% I'i organik tarım üretimi yapılan alanlardır. Kiși bașı organik gıda harcamasında İsviçre 262 Euro ile ilk sırada yer alırken, İsviçre'yi I9I Euro ile Danimarka, 177 Euro ile İsveç ve 170 Euro ile Lüksemburg izlemektedir. Avrupa Birliği genelinde ise kiși bașı organik gıdaya ayrılan bütçe 53.7 Euro olarak hesaplanmıștır (Ceylan, 20ı7). Gıda, Tarım ve Hayvancılık Bakanlığı ve TÜÍK (2017) yılı verilerine göre Türkiye'de 67, 878 üreticinin, toplam 523, 777 hektar alanda, 238 çeșit ürün ve
2, 473, 600 ton üretim miktarı ile organik tarım yaptığı saptanmıștır. Türkiye'de üretim miktarlarına bakılarak Ayla ve Altıntaș (2017) tüketici talepleri doğrultusunda önem kazanan organik pazarın büyümekte olduğunu ifade etmișlerdir. Organik tarım geçiș sürecinin de eklendiği Gıda, Tarım ve Hayvancılık Bakanlığı (2016) verilerine göre, Siirt ilindeki organik üretici sayısı 6, organik üretim alanı I4 ha ve 345 tonu Nar ve I tonu Antepfıstığı olmak üzere toplam 346 ton üretim gerçekleșmiș, organik hayvansal üretim de ise arıcılık faaliyetlerinde 6 adet üretici olduğu, 1793 adet kovan sayısı ve 15 ton bal üretimi olduğu belirlenmiștir. 2016 yılında ürün sayısı yaklașık olarak \%2l artmıș, çiftçi sayısı \%3 azalmıștır. Alanda \%2, üretim de \%35, ihracatta

Sorumlu Yazar: karakayaersin@hotmail.com Geliș Tarihi: 8 Mayıs 2018

Kabul Tarihi: 15 Kasım 2018 
\%24 ve ithalatta ise \%228 artıș sağlanmıștır (Çizelge I). En fazla incir ve incir ürünleri, kuru üzüm ve fındık ve fındık ürünleri $A B D$, Almanya ve Kuzey Kıbrıs Türk Cumhuriyeti 'ne (KKTC) ihraç edilirken, Rusya'dan Mısır, Rusya Etiyopya ve Ukrayna'dan Soya fasulyesi (tohumluk olmayan) ve Rusya İsrail ve yeni Zelenda'dan ise Buğday ithal edilmiștir.

Çizelge I. 20I5-2016 yılı Türkiye organik tarım verileri

\begin{tabular}{lllllll}
\hline Yıllar & Ürün sayısı & Çiftçi sayısı & Alan (ha) & Üretim (Ton) & İhracat (Ton) & İthalat (Ton) \\
\hline 2015 & 197 & 69,967 & 515,268 & $1,829,291$ & 13,548 & 200,196 \\
2016 & 238 & 67,878 & 523,777 & $2,473,600$ & 16,819 & 658,354 \\
\% Değișim & 21 & 3 & 2 & 35 & 24 & 228
\end{tabular}

Daha fazla organik ürün tüketme isteğinin ve daha fazla organik ürün üretme gerekliliğinin en önemli nedeni tüketici ve çevre odaklı yaklașımlardır (Ustaahmetoğlu ve Toklu, 2015; İnci ve ark., 2017). Sağlığa zararlı olmaması düșüncesi, gıda güvenliği, hayvan refahının sağlanması, çevrenin korunması ve sertifikalı olması gibi nitelikleri tüketicilerin satın alma kararlarını alırken diğer ürünlere göre organik ürünleri tercih etme nedenlerinin en önemlilerindendir (Ankomah ve Yiridoe, 2006; Eryllmaz ve ark., 2015; İnci ve ark., 2017).

Organik tarım ve organik tarım ürünlerine karșı tüketici davranıșlarına yönelik Torjusen ve ark. (200I), Magnusson ve ark. (2003), Saba ve Messina (2003), Sanjuán ve ark. (2003), Armağan ve Özdoğan (2005), Gifford ve Bernard (2006), Chen (2007) Sarıkaya, (2007), Arvola ve ark. (2008), Kacur (2009), Akın ve ark. (2010), Gündüz ve Bayramoğlu (20II), Karabaș ve Gürler (20I2), Tetik (20I2), Çelik (2013), Kaya Erem ve Atsan (20/3), Inci ve ark. (20/4) Eryılmaz ve ark. (20I5), Onurlubaș ve Öztürk (20I5), Ustaahmetoğlu ve Toklu (2015), Onurlubaș ve Doğan (2016), Varoğlu ve Turhan (2016), Cengiz ve Șenel (2017), İnci ve ark. (2017) tarafından birçok çalıșma yapılmıștır. Ayrıca Merdan ve Kaya (2013) Türkiye'de organik tarımın ekonomik analizi, Ataseven ve Güneș (2008) ve Gök (2008) Türkiye'de organik ürün üretimi ve ticareti, Bayram ve ark (2007) ve Ayla ve Altıntaș (2017) Türkiye'de organik tarım ve sorunları üzerine çalıșma yapmıșlardır.

$\mathrm{Bu}$ çalıșma, Siirt il merkezindeki tüketicilerin organik ürünlere yönelik tercihlerini ve organik ürünleri tercih etmelerinde etkili olan faktörleri belirlemek amacıyla yapılmıștır.

\section{MATERYAL ve YÖNTEM}

$\mathrm{Bu}$ çalıșmanın materyalini, Siirt ili kent merkezinde örnekleme metoduyla belirlenen bireylerin organik ürünlerin tüketimi hakkındaki bilgi düzeylerinin ve tercihlerinin tespit edilmesi için yapılan anketlerden elde edilen veriler olușturmuștur. Anketler, 2017 yılında Siirt kent merkezinde yapılmıștır. Bu çalışmada, ayrıca TÜIK ve ilgili diğer kurum ve kurulușların ve daha önce yapılmıș çalıșmaların bulgularından da faydalanılııștır.

Örnek hacmini (anket yapılan tüketici sayısı) belirlemek için așağıdaki formül kullanılmıștır (Baș, 2008; Gözener ve Sayılı, 2013).

$$
n=\frac{N \times t^{2} \times p \times q}{d^{2} \times(N-1)+t^{2} \times p \times q}
$$

Formülde;

n: Örneğe alınacak birey sayısı,

$\mathrm{N}$ : Hedef kitledeki birey sayısı (I6I, 423),

$\mathrm{p}$ : Incelenen olayın gerçekleșme olasılı̆̆ı $(0.50)$,

q: İncelenen olayın gerçekleșmeme olasılı̆̆ $(0.50)$,

t: Standart normal dağılım değeri (I.65),

$\mathrm{d}$ : Örnekleme hatası (0.05)'dır.

Formülde $\% 90$ güven aralığı, $\% 5$ hata payı ve maksimum örnek hacmine ulașabilmek için $p=q=0.5$ olarak alınmıș ve örnek hacmi 27I olarak hesaplanmıștır.

Anketten elde edilen veriler SPSS 17.0 (Statistical Package for Social Sciences) paket programında analiz edilmiștir. Analiz kapsamında, frekans tabloları, pasta ve çubuk grafikler, $X 2$ testi, bağımsız örneklem $t$ testi ve Tek Yönlü Varyans (ANOVA) Analizi'nden faydalanıımıștır. Tek Yönlü Varyans analizinde farklılığın hangi gruplardan kaynaklandığını belirlemek için Duncan testi kullanılmıștır.

\section{BULGULAR ve TARTIȘMA}

\section{Bireylerin Sosyo- Ekonomik ve Demografik Özellikleri}

Bireylerin sosyo-ekonomik ve demografik özellikleri Çizelge 2'de verilmiștir. Bireylerin \%63'ünün erkek, \%7l'inin bekâr, $\% 42$ 'sinin $26-35$ yaș arasında ve yaș ortalamasının 34.2 ve \%46.5'inin I00I-I500 TL arasında aylık gelire sahip ve aylık gelirlerinin ortalama $1200 \mathrm{TL}$ olduğu belirlenmiștir. İlköğretim mezunu olan bireylerin oranı \%23.9, ortaokul mezunu olan bireylerin oranı \%22.5, lise mezunu olan bireylerin oranı \%16.9 ve üniversite ve lisansüstü mezunu olan bireylerin oranı ise sırasıla $\% 28$ ve $\% 8.7$ olarak bulunmuștur. Meslek grupları itibariyle bireylerin \%22.l'inin diğer meslek (özel sektör veya belirtmek istenmeyen meslek) grubunda, oldukları belirlenirken bu grubu sırasıyla \%20.2 ile işçi grubundaki bireyler, \% 17.7 ile memur grubundaki bireyler ve \%।4.6 ile ev hanımı grubundaki bireyler takip etmiștir. Ailedeki birey sayısının dağııımı incelendiğinde anket yapılan bireylerin büyük bir kısmında (\%65.7) ailelerin 4 ten fazla bireyden oluștuğu sonucu saptanmıștır. 
Çizelge 2. Bireylerin sosyo-ekonomik ve demografik özellikleri

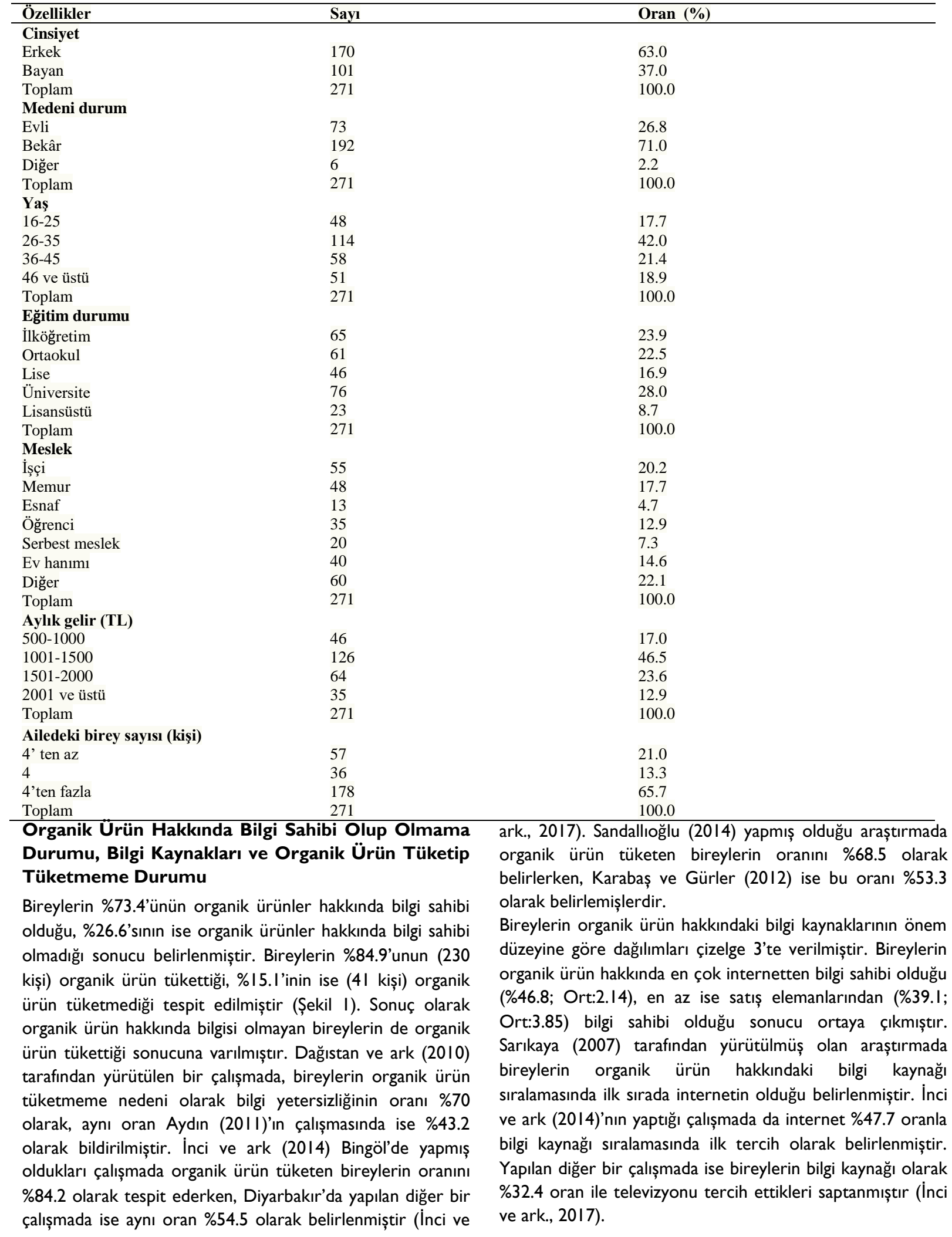




\section{Bilgi Sahibi Olup Olmama Durumu}

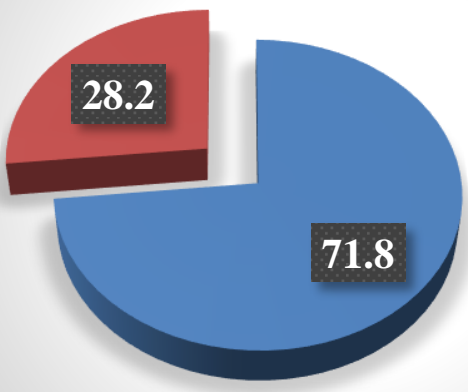

Organik Ürün Tüketip

Tüketmeme Durumu

\section{7}

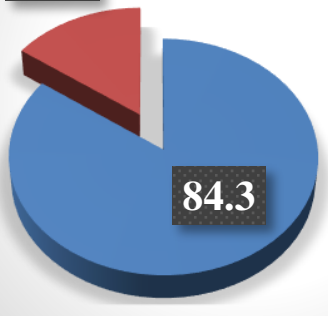

Evet

Hayır

Șekil I. Organik ürün hakkında bilgi sahibi olup olmama durumu ve organik ürün tüketip tüketmeme durumu (\%)

Çizelge 3. Bireylerin organik ürün hakkındaki bilgi kaynaklarının önem düzeyi

\begin{tabular}{lllllll}
\hline Bilgi kaynakları & $\mathrm{I}(\%)$ & $2(\%)$ & $3(\%)$ & $4(\%)$ & $5(\%)$ & Ortalama \\
\hline Internet & 46.8 & 19.8 & 14.2 & 8.9 & 10.3 & $\mathbf{2 . 1 4}$ \\
TV & 20.3 & 44.6 & 16.6 & 12.2 & 6.3 & 2.39 \\
Eș dost tavsiyesi & 19.9 & 16.2 & 22.1 & 23.6 & 18.1 & 3.03 \\
Dergi gazete & 4.1 & 12.9 & 35.1 & 22.9 & 26.2 & 3.56 \\
Satıș elemanları & 8.9 & 7.4 & 12.5 & 32.1 & 39.1 & 3.85
\end{tabular}

I: En çok; 2: Çok; 3: Orta; 4: Az; 5: En az

Bireylerin Tükettiği Organik Ürün Grubu ve Tüketim Tercihini Etkileyen Faktörler

Bireylerin tükettiği organik ürün gruplarının oransal dağılımı Șekil 2'de verilmiștir. Bireylerin büyük bir kısmı (\%62.2) organik yaș sebze ve meyve tükettiğini, \%/6.7'si organik salça, zeytinyağı tükettiğini, \% 2.9 'u organik içecekler tükettiğini belirtmișlerdir. Organik sabunlar, güzellik ürünleri gibi ürünlerin tüketilme oranı $\% 4.5$, organik baharat, kuru gıdaların tüketilme oranı ise \%3.7 olarak saptanmıștır. İnci ve ark (2014; 2017)'nın Bingöl ve Diyarbakır illerinde yürüttüğü çalıșmalarda da bireylerin organik yaș sebze ve meyve gruplarını \%60.6 ve \%43.4 ile ilk sırada tercih ettikleri belirlenmiștir. Çalıșma sonuçları İnci ve ark (2014; 2017)'nın çalıșma sonuçlarıyla benzer bulunmuștur. 34 yașın altındaki bireylerin diğer yaș gruplarına göre daha fazla oranda yaș sebze ve meyve tükettikleri $\left(X^{2}=34.146 ; p=0.001\right)$, yaș sebze ve meyve tüketen bireylerin oranı memur ve öğrenci olan meslek gruplarında diğer meslek gruplarına göre daha yüksek $\left(X^{2}=37.096 ; P=0.002\right)$ ve yaș sebze ve meyve tüketen bireylerin oranının üniversite mezunları grubunda diğer eğitim gruplarına göre daha fazla $(X 2=29.742 ; \quad P=0.019)$ olarak belirlenmiștir.

\section{Tüketilen organik ürün grubu}

\section{2}

\section{$\begin{array}{llll}3.7 & 12.9 & 16.7 & 4.5\end{array}$}

$\square$ Organik yaş sebze ve meyve

$\square$ Organik içecekler

$\square$ Organik sabunlar, güzellik ürünleri vb. $\square$ Organik baharat, kuru gidalar

$\square$ Organik salça, zeytinyağı vb.

Șekil 2. Bireylerin tükettiği organik ürün grubu (\%)

36 
Bireylerin organik ürün gruplarını tercih etmelerinde etkili olan faktörlerin oransal dağılımı ve ortalama değerleri Çizelge 4'te verilmiștir. Sağlığa zararlı olmaması faktörünün 2.50 ortalama ve \%26 oranla en çok etkili faktör olduğu, fiyat faktörünün ise 4.02 ortalama ve \%।3.2 oranla en az etkili faktör olduğu belirlenmiștir. Organik ürün tercihinde sağlığa zararlı olmaması, sağlıklı ve güvenli olması gibi faktörler daha önce farklı illerde yapılmış olan Armağan ve Özdoğan (2005), Karabaș ve Gürler (2012) ve İnci ve ark (2014; 20I7) birçok çalıșmada da en etkili faktör olarak bildirilmiștir.

Çizelge 4. Bireylerin organik ürün tüketim tercihini etkileyen faktörler

\begin{tabular}{lllllll}
\hline Faktörler & $\mathrm{I}(\%)$ & $2(\%)$ & $3(\%)$ & $4(\%)$ & $5(\%)$ & Ortalama \\
\hline Fiyatı & 13.2 & 4.4 & 7 & 11.2 & 64.2 & 4.02 \\
Besin değeri & 17.5 & 15.5 & 21.4 & 31 & 11.1 & 2.95 \\
Güvenli olması & 24.7 & 30.7 & 26.8 & 15.6 & 4.1 & 2.59 \\
Sağlığa zararlı olmaması & 26 & 34.3 & 22.2 & 17.7 & 4.8 & $\mathbf{2 . 5 0}$ \\
Doğal ve ekolojik olması & 18.6 & 15.1 & 22.5 & 22.5 & 16.2 & $\mathbf{2 . 9 2}$ \\
\hline
\end{tabular}

I: En çok; 2: Çok; 3: Orta; 4: Az; 5: En az

Bireylerin Organik Ürünlere Yönelik Düșünceleri

Bireylerin organik ürünler hakkındaki bazı ifadelere katılıp katılmama durumlarının dağılımı oransal ve ortalama olarak analiz edilmiș ve sonuçlar Çizelge 5'te verilmiștir. Bireylerin \%81.2'sinin organik ürün tüketmek gerekir, \%67.5'inin son kullanma tarihine dikkat ederim \%49.8'inin ambalaj üzeri bilgiyi dikkate alırım, \%42.4'ünün ise organik olmayan ürünler sağlığa zararlıdır ifadelerine kesinlikle katıldıkları

Çizelge 5. Bireylerin organik ürünler hakkındaki ifadelere katılım durumu

\begin{tabular}{|c|c|c|c|c|c|c|}
\hline İfadeler & I (\%) & $2(\%)$ & $3(\%)$ & $4(\%)$ & $5(\%)$ & Ortalama \\
\hline Organik ürün tüketmek gerekir & 81.2 & 14.8 & 1.8 & 1.5 & 0.7 & 1.25 \\
\hline Son kullanma tarihine dikkat ederim & 67.5 & 25.8 & 3.7 & 1.8 & I.I & 1.43 \\
\hline Ambalaj üzeri bilgiyi dikkate alırım & 49.8 & 34.7 & 10.7 & 4.4 & 0.4 & 1.70 \\
\hline Organik olmayan ürünler sağlığa zararlıdır & 42.4 & 28.4 & 17.3 & 9.2 & 2.6 & 2.01 \\
\hline Organik ürünlerin pahalı olması normaldir & 21.8 & 25.8 & 14.4 & 25.8 & 12.2 & 2.81 \\
\hline Kullandığım ürünler sağlığım açısından son derece faydalıdır & 30.6 & 40.6 & 18.5 & 7.7 & 2.6 & 2.11 \\
\hline Çevre için olumsuz olan ürünü satın almam & 41.3 & 32.5 & 17.7 & 5.9 & 2.6 & 1.95 \\
\hline Hormonlu ürünleri almamaları için çevremdekileri uyarırım & 33.9 & 38 & 17 & 5.2 & 5.9 & 2.11 \\
\hline Organik ürünlerin kontrol ve denetimi hakkında bilgi sahibiyim & 15.5 & 34.7 & 26.2 & 14.8 & 8.9 & 2.66 \\
\hline Promosyon ve indirimleri takip ederim & 15.5 & 26.6 & 25.5 & 19.9 & 12.5 & 2.87 \\
\hline Reklamlar insanları daha fazla organik ürün tüketmeye yöneltir & 26.2 & 28.4 & 12.2 & 17.3 & 15.9 & 2.68 \\
\hline
\end{tabular}

I: Kesinlikle katılıyorum; 2: Katılıyorum; 3: Kararsızım; 4: Katılmıyorum; 5: Kesinlikle katılmıyorum

sonucu belirlenmiștir. Bireylerin organik ürünlerin kontrol ve denetimi hakkında bilgi sahibiyim ve promosyon ve indirimleri takip ederim ifadelerine katılım durumlarına bakıldığında diğer ifadelere nazaran daha fazla kararsız oldukları tespit edilmiștir. Organik ürünlerin pahalı olması normaldir fikrine katılmayan bireylerin oranı \%25.8, reklamların organik ürün tüketme üzerinde olumlu etkisine kesinlikle katılmayan bireylerin oranı ise \% I5.9 olarak bulunmuștur. Bireylerin sosyo ekonomik ve demografik özellikleri ile organik ürünler hakkındaki ifadeler arasındaki ilișkiler incelenmiș, yapılan analiz sonucunda $200 \mathrm{I} T \mathrm{TL}$ ve üstü gelir grubundaki bireylerin diğer gelir grubundaki bireylere nazaran organik ürünlerin son kullanma tarihine daha fazla dikkat ettikleri $(F=6.267 ; p=0.000)$ belirlenmiștir. Organik ürünlerin son kullanma tarihine bayanların erkeklere nazaran daha çok dikkat ettiği ve bu durumun da istatistiki olarak önemli olduğu belirlenmiștir $(t=2.477 ; P=0.014)$. İş̧i ve esnafların diğer meslek grubundaki bireylere göre organik ürünlerin son kullanım tarihine dikkat etme ifadesine daha az katıldıları saptanmıștır $(\mathrm{F}=3.88 \mathrm{P} ; \mathrm{P}=0.004)$. Evli olan bireylerin promosyon ve indirimleri takip etme fikrine diğer bireylere göre daha fazla oranda katıldıkları $(F=5.643 ; P=0.004)$, dul veya boșanmıș bireylerin ise diğer bireylere nazaran organik ürünlerin pahalı olması normal ifadesine daha fazla katıldıkları sonucu bulunmuștur $(F=4.388 ; \quad P=0.013)$. Hormonlu ürünleri almamaları için çevremdekileri uyarırım ifadesine bekârların diğer bireylere göre daha az katıldıkları belirlenmiștir ( $F=3.470 ; P=0.033)$. 16-25 yaș ve 46 ve üstü yaș grubunda yer alan bireylerin diğer yas, grubunda yer alan bireylere göre çevreye olumsuz etkisi olduğunu öğrendiğim ürünü satın almayı bırakırım ifadesine katılım oranları düșüktür ( $F=3.423 ; P=0.018)$. Organik ürünlerin kontrol ve denetimi hakkında bilgi sahibiyim ifadesine katılım durumu eğitim grupları arasında önemli ilișkiler belirlenmiș özellikle ilköğretim mezunu olan bireylerin bu fikre katılma noktasında tamamen kararsız olduğu beklenen bir sonuçtur. Ancak üniversite ve lisansüstü grubunda yer alan bireylerin 
de bu ifadeye katılım durumları açısından verdikleri cevaplar daha çok kararsızım olarak saptanmıștır ( $\mathrm{F}=2.797 ; \mathrm{P}=0.027)$. Hjelmar (20II) tarafından yapılan bir çalıșmada organik ürünlerin çevreye olumsuz etkisinin olmaması ve ambalaj üzeri bilgiyi dikkate alırım ifadelerine bireylerin çok daha fazla önem verdikleri sonucu belirlenmiștir. Ustaahmetoğlu ve Toklu (20I5) tarafından yürütülmüș olan bir çalıșmada, meslek grupları ve organik gıdalara yönelik tutum arasında ve cinsiyet ile de satın alma niyeti arasında ilișki olduğu belirlenmiștir. Daha önce yapılan bir çalıșmada, organik ürünlerin pahalı olmasının normal olması ifadesinin yașa, eğitime, gelire, yașanılan kiși sayısına göre, çevreye olumsuz etkisi olan ürünün satın alınmaması ifadesinin eğitime göre, organik olmayan ürünlerin sağlığa zararlı olması ifadesinin eğitime göre değiștiği bildirilmiștir (Sarıkaya, 2007). Bireylerin \%9।.9'u organik ürünler hakkında tanıtımın yeterli olmadığını ifade ederken, \%70.l'i yașadıkları bölgede organik ürünlerin her yerde bulunduğunu ifade etmișlerdir. Ankete katılan bireylerin \%89.7'si organik ürünlerin pahalı olduğunu düșünmekte, bireylerin \%42.l’i üretim miktarının az olmasından dolayı, \%31.7'si üretim maliyetinin yüksek olmasından dolayı ve \%26.2'si ise üretimin zor olmasından dolayı bu düșünceye sahip olduklarını belirtmișlerdir. Organik ürün alırken ambalajına bakarak alan bireylerin oranı \%50.2, etiketine bakarak alan bireylerin oranı $\% 32.5$ ve logosuna bakarak alan bireylerin oranı ise \%17.3 olarak tespit edilirken, bireylerin \%79'unun organik ürün alırken markasına dikkat ettiği belirlenmiștir. Mevsimler itibariyle bireylerin \%67.5 oranında yazın, \% I7 oranında kıșın, \% II.4 oranında ilkbahar ve \%4.I oranında ise sonbaharda organik ürün tükettikleri sonucu bulunmuștur.

\section{Organik Ürünlerin Satın Alındığı Yer ve Satıș Yerini Etkileyen Faktörler}

Bireylerin \%65.3'ünün organik ürünleri köylerden, \%22.9'unun organik ürün satan marketlerden ve \%II.8'inin ise süpermarketlerden satın aldığı tespit edilmiștir (Șekil 3).

\section{Satın alınan yer}

65.3

22.9

11.8

\section{Köylerden $\square$ Organik ürün satan marketlerden $\square$ Süpermarketlerden}

Șekil 3. Organik ürünlerin satın alındığı yer (\%)

Karabaș ve Gürler (20I2), Sandallıoğlu (20I4) ve İnci ve ark (2017) tarafından yapılan çalıșmalarda, bireylerin organik ürünleri sırasıyla \%63.5, \%44 ve \%54 oranında süpermarketten aldıkları sonucu bildirilmiș ve bulunan bu değerlerin çalșmada bulduğumuz değerin çok üstünde olduğu belirlenmiștir. Varoğlu ve Turhan (20l6) tarafından yapılan araștırmada, organik ürün satıș yeri tercihi cinsiyet ve gelir grupları bakımından karșılaștıııımıș kadın ve erkeklerin genel olarak \%49.6 oranında organik ürün satın aldığı yer market olarak belirlenmiștir. Düșük gelirli bireylerin market veya kendi üretimi olan ürünleri tercih ettiği, yüksek gelirli bireylerin ise pazardan satın aldıkları sonucu belirlenmiștir. Siirt ilinde organik ürün tüketen bireylerin bu ürünleri köylerden almasının en büyük sebebini bu ürünleri doğrudan üreticiden almak istemeleri șeklinde ifade etmișlerdir.

Organik ürün satıș yerini etkileyen faktörlerin önem düzeylerine ait analiz yapılmıș ve sonuçlar Çizelge 6'da verilmiștir. Bireylerin \%55.7'sinin organik ürün satıș yeri

Çizelge 6. Organik ürün satıș yerini etkileyen faktörlerin önem düzeyleri

\begin{tabular}{lllllll}
\hline Faktörler & $\mathrm{I}(\%)$ & $2(\%)$ & $3(\%)$ & $4(\%)$ & $5(\%)$ & Ortalama \\
\hline Temizlik, hijyen & 55.7 & 21 & 9.2 & 6.6 & 7.4 & $\mathbf{1 . 8 8}$ \\
Tavsiye & 6.6 & 19.6 & 25.1 & 29.2 & 19.6 & $\mathbf{3 . 3 5}$ \\
Firma güvenirliği & 17 & 39.1 & 19.6 & 14 & 10.3 & $\mathbf{2 . 6 1}$ \\
Uygun fiyat & 9.2 & 8.5 & 17 & 22.1 & 43.2 & $\mathbf{3 . 8 I}$ \\
Ürün çeșitliliği & 11.4 & 11.8 & 29.2 & 27.7 & 19.9 & $\mathbf{3 . 3 2}$ \\
\hline
\end{tabular}

I: En çok; 2: Çok; 3: Orta; 4: Az; 5: En az 
tercihinde temizlik ve hijyen faktörünün 1.88 ortalama değer ile en çok etkili olduğu, en az etkili olan faktörün ise \%43.2 oran ve 3.81 ortalama değer ile fiyat faktörünün olduğu belirlenmiștir. Sarıkaya (2007) tarafından yapılan çalıșmada da temizlik ve hijyen faktörü I. Sırada, güven faktörü ise 2. Sırada olarak bildirilmiștir. Diyarbakır ilinde İnci ve ark (2017)'nın yapmıș olduğu çalıșmada da satıș yeri tercihinde temizlik ve güven faktörleri $\% 5$ I ve $\% 22$ oranla ilk sırada önemli bulunan faktörler olarak belirlenmiștir.

\section{SONUÇ}

Bireylerin organik ürün hakkında en çok internetten bilgi sahibi olduğu, en az ise satıș elemanlarından bilgi sahibi olduğu sonucu ortaya çıkmıș, genel sonuç olarak; bireylerin organik ürünler hakkında bilgi sahibi olmasında kitle iletișim araçlarının daha çok etkin olduğu kanısına varılmıștır. Bireylerin büyük bir kısmı (\%62.2) organik yaș sebze ve meyve tükettiğini belirtmișlerdir. Özellikle üniversite mezunu öğrenci veya memur olan 34 yașından küçük bireylerin daha fazla oranda organik yaș sebze ve meyve tükettikleri belirlenmiștir. Bireylerin organik ürün tercihinde sağlığa zararlı olmaması faktörünün en çok etkili faktör olduğu, fiyat faktörünün ise en az etkili faktör olduğu belirlenmiștir. Bireylerin organik ürünlerin kontrol ve denetimi hakkında bilgi sahibiyim ve promosyon ve indirimleri takip ederim ifadelerine katılım durumlarına bakıldığında diğer ifadelere nazaran daha fazla kararsız oldukları tespit edilmiștir. Organik ürünlerin son kullanma tarihine yüksek gelir grubundaki bireylerin diğer gelir grubundaki bireylere göre ve bayanların erkeklere göre daha fazla dikkat ettikleri saptanmıștır. Organik ürünlerin kontrol ve denetimi hakkında bilgi sahibiyim ifadesine katılım durumu eğitim grupları arasında önemli ilișkiler belirlenmiș özellikle ilköğretim mezunu olan bireylerin bu fikre katılma noktasında tamamen kararsız olduğu beklenen bir sonuçtur. Ancak üniversite ve lisansüstü grubunda yer alan bireylerin de bu ifadeye katılım durumları açısından verdikleri cevaplar daha çok kararsızım olarak saptanmıștır. Bireylerin büyük bir kısmı organik ürünler hakkında tanıtımın yeterli olmadığını ifade ederken, yaklașık olarak \%70'i yașadıkları bölgede organik ürünlerin her yerde bulunduğunu ifade etmișlerdir. Ankete katılan bireylerin çoğunluğu organik ürünlerin pahalı olduğunu düșünmekte, bireylerin \%42.l'i üretim miktarının az olmasından dolayı, \%3।.7'si üretim maliyetinin yüksek olmasından dolayı ve \%26.2'si ise üretimin zor olmasından dolayı bu düșünceye sahip olduklarını belirtmișlerdir. Mevsimler itibariyle bireylerin büyük bir kısmının yazın, organik ürün tükettikleri sonucu bulunmuștur. Bireylerin büyük bir kısmının organik ürünleri köylerden, satın aldığı tespit edilmiș, bunun en büyük sebebinin bireylerin bu ürünleri doğrudan üreticiden almak istediklerini ifade etmeleri olarak belirlenmiștir. Bireylerin temizlik ve hijyen olarak uygun buldukları ve güvendikleri yerlerden organik ürün aldıkları kanısına varılmıștır. Sonuç olarak; organik ürünlerin güvenli olması ve organik ürünlerinin sağlığa zararlı olmaması, gibi faktörlerin organik ürün tüketim tercihini etkileyen en önemli faktörler olduğu saptanmıștır. Kontrol ve sertifikasyon ile ilgili olarak tüketici bilincinin olușmaması, reklam faaliyetlerinin yetersiz kalması ve pazarlama önemli sorunlar arasında yer almaktadır. Pazarlama marjının tüketici lehine olması, organik ürün satıș yerinin güvenilirliği ve temizliğine yönelik yapılacak çalıșmaların organik ürünlerin tüketimini arttıracağı sonucuna varılmıștır.

Siirt ilinde organik ürün tüketimini arttırmak için ürün çeșitlemesinde bireylerin tercih ettiği ürün gruplarında doğru pazarlama stratejilerinin belirlenmesi ve uygulanması son derece önemlidir. Özellikle köylerdeki üreticilerin projeler dâhilinde daha planlı ve etkin olarak organik tarıma geçmesini sağlayacak adımlar atılmalıdır. Bireylerin organik tarım ve gıda ürünlerine erișebilirliğini kolaylaștırmak için organik pazar sayılarının artırılması gereklidir. İnternet aracılığıyla yapılacak satıșlar organik ürün tüketiminin artmasını sağlayabilir. Organik üreticilerin; bütün organik ürün tüketicilerine hitap edecek, tüketici merkezli bir pazarlama politikası belirlemeleri ve stratejilerine bu doğrultuda yön vermeleri son derece önemlidir.

\section{KAYNAKLAR}

Akın, M., Çiçek, R., İnal, M. E., Toksarı, M. 2010. Niğde İlindeki tüketicilerin sosyo-demografik özellikleri ile organik gıdalara ilișkin tutum ve bireysel değerleri arasındaki farklılığın incelenmesine yönelik bir araștırma. Dokuz Eylül Üniversitesi Sosyal Bilimler Enstitüsü Dergisi, I2(I): 29-56.

Ankomah, S. B., Yiridoe, E. K. 2006. Organic and Conventional Food: A Literature Review of the Economics of Consumer Perceptions and Preferences. Organic Agriculture Centre of Canada Nova Scotia Agricultural College, $59 \mathrm{~s}$.

Armağan, G., Özdoğan, M. 2005. Ekolojik yumurta ve tavuk etinin tüketim eğilimleri ve tüketici özelliklerinin belirlenmesi. Hayvansal Üretimi, 46 (2): |4-2I.

Arvola, A., Vassallo, M., Dean, M., Lampila, P., Saba, A., Lahteenmaki, L., Shepherd, R. 2008. Predicting Intentions to purchase organic food: the role of affective and moral attitudes in the theory of planned behaviour. Appetite, 50: 443-454.

Ataseven, Y., Güneș, E. 2008. Türkiye'de İșlenmiș Organik Tarım Ürünleri Üretimi ve Ticaretindeki Gelișmeler. Uludağ Üniversitesi Ziraat Fakültesi Dergisi, 22(2).

Aydın, G. 20II. Tüketicilerin Gıda Güvenliği Bilinç Düzeylerine Etki Eden Faktörlerin Analizi: Samsun İli Kentsel Alan Örneği. Ondokuz Mayıs Üniversitesi, Fen Bilimleri Enstitüsü, Yüksek Lisans Tezi, 85 s.

Ayla, D., Altıntaș, D. 2017. Organik Üretim Ve Pazarlama Sorunları Üzerine Bir Değerlendirme. Kastamonu Üniversitesi İktisadi ve İdari Bilimler Fakültesi DergisiCilt 19, Sayı 4,2017

Bayram, B., Yolcu, H., Aksakal, V. 2007. Türkiye'de Organik Tarım ve Sorunları. Atatürk Üniversitesi Ziraat Fakültesi Dergisi, $\quad 38 \quad$ (2): 
Baș, T. 2008. Anket. Araștırma Yöntemleri Dizisi: 2. Seçkin Yayıncılık, 5. Baskı, Ankara, s. 255.

Cengiz, H., Șenel, M. 2017. Tüketicilerin Organik Gıda Satın Alma Motivasyonlarının Zaltman Metafor Çıkarım Tekniği Aracılığıyla İncelenmesi. Karabük Üniversitesi Sosyal Bilimler Enstitüsü Dergisi, 2017, 7 (I), 56-69

Ceylan, S. 2017. Organik tarıma genel bakıș. (http://www.dunyagida.com.tr) (Erișim tarihi: 20.04.20189

Chen, M. F. 2007. Consumer Attitudes and Purchase Intentions in Relation to Organic Foods in Taiwan: Moderating Effects of Food-Related Personality Traits. Food Quality and Preference 18: 1008-1021.

Çelik, S. 2013. Kimler, Neden Organik Gıda Satın Alıyor? Bir Alan Araștırması. Selçuk Üniversitesi Sosyal Bilimler Enstitüsü Dergisi, 30:93-108.

Dağıstan, E., Demirtaș, B., Yılmaz, Y., Tapkı, N. 2010. Organik Ürün Tüketim Eğilimi."Türkiye IX. Tarım Ekonomisi Kongresi 22-24 Eylül 2010, Șanlıurfa”. Kongre Bildiri Kitabı (Editörler: B. Karlı, R. Özel, F.Ö. Kara), s: 312-319.

Eryılmaz AG, Demiryürek K, Emir M 2015. Avrupa Birliği ve Türkiye'de Organik Tarım ve Gıda Ürünlerine Karșı Tüketici Davranıșları. Anadolu Tarım Bilimleri Dergisi. Anadolu I Agr Sci, 30: 199-206.

FiBL, 2017. http://www.fibl.org (Erișim tarihi,20.04.2018).

Gifford, K, Bernard, I. C. 2006. Influencing Consumer Purchase Likelihood of Organic Food. International Journal of Consumer Studies, 30: I55-163.

Gök, Seçil Adalet 2008. Genișleyen Avrupa Birliği Pazarında Türkiye'nin Organik Tarım Ürünleri Ticareti Açısından Değerlendirilmesi, AB Uzmanlık Tezi, Tarım ve Köy İșleri Bakanlığı Dıș İlișkiler ve Avrupa Birliği Koordinasyon Dairesi Bașkanlığı, Ankara.

Gözener, B., Sayılı M. 2013. Tüketicilerin Açık Süt ve Süt Ürünleri Tüketim Tercihlerinin İncelenmesi: TokatTurhal Olçesi Örneği. Sosyal Bilimler Arastırmaları Dergisi. I, (20I3): I60-I75

Gündüz, O, Bayramoğlu, Z. 20I I. Consumer's Willingness to Pay for Organic Chicken Meat in Samsun Province of Turkey. Journal of Animal and Veterinary Advances, 10 (3): 334-340.

Hjelmar, U. 20II. Consumers' Purchase of organic food products. a matter of convenience and reflexive practices. Appetite, 56: 336-344.

IFOAM 2017. The World of Organic Agriculture 2017. (www.organic-world.net) (Erișim Tarihi: 28.03. 2018)

İnci H, Karakaya E, Söğüt B, Șengül T 20I4. Organic Product Consumption and Customer Preferences in Urban Sections of Bingol Province. Türk Tarım ve Doğa Bilimleri Dergisi I (2): 255-26I.

İnci, H., Karakaya E, Șengül, Y.A. 2017. Organik Ürün Tüketimini Etkileyen Faktörler (Diyarbakır İli Örneği) KSÜ Doğa Bil. Dergisi., 20(2), I37-|47, 2017

Kacur L 2009. Erciyes Üniversitesi İ̈BF Akademik ve İdari Personeli ile İ̈BF İșletme Gündüz ve İkinci Öğretim Öğrencilerinin Organik Ürünleri Algılamaları. Erciyes Üniversitesi İktisadi ve İdari Bilimler Fakültesi Dergisi, 33: 249-277.
Karabaș S, Gürler ZA 2012. Organik Ürün Tercihinde Tüketici Davranıșları Üzerine Etkili Faktörlerin Logit Regresyon Analizi ile Tahminlenmesi. Adıyaman Üniversitesi Sosyal Bilimler Enstitüsü Dergisi, 5 (I0): 129-156.

Kaya Erem T, Atsan T 2013. Kırsal Kadının Organik Tarımı Benimsemesini Etkileyen Faktörler Üzerine Bir Araștırma (TRAI Bölgesi Örneği). Atatürk Üniversitesi, Ziraat Fakültesi Dergisi, 44( I ): 43-49.

Magnusson, M. K, Arvola, A, Hursti, UK, Aberg, L, Sjoden, P. 2003. Choice of organic foods is related to perceived consequences for human health and to environmentally friendly behaviour. Appetite, 40: 109-II7.

Merdan, K., Kaya, V. 2013. Türkiye'deki Organik Tarımın Ekonomik Analizi. Atatürk Üniversitesi Sosyal Bilimler Enstitüsü Dergisi 2013 I7 (3): 239-252

Onurlubaș, E., Öztürk, D., 2015. "Factors That Affect Organic Product Preference And Consumer Attitudes / Organik Ürün Tercihini Etkileyen Faktörler ve Tüketici Davranıșları", TURKISH STUDIES -International Periodical for the Languages, Literature and History of Turkish or Turkic-, ISSN: 1308-2140, (Prof. Dr. H. Ömer Karpuz Armağanı), Volume 10/14 Fall 2015, ANKARA/TURKEY, www.turkishstudies.net, DOI Number: (http://dx.doi.org), p. 557-578.

Onurlubaș, E., Doğan G.H. 2016. Türkiye' De Organik Ürün Tüketiminin Mevcut Durumu Ve Tüketici Eğilimleri. AKADEMIK BAKIȘ DERGİII Sayı: 54 Mart - Nisan 2016 Uluslararası Hakemli Sosyal Bilimler E-Dergisi.

Saba, A., Messina, F. 2003. Attitudes towards organic foods and risk/benefit perception associated with pesticides. Food Quality and Preference, 14, 637-645.

Sandallığlu A 2014. Adana İlinde Organik Tarım Ürünleri Tüketimi ve Tüketici Eğilimleri. Cukurova Üniversitesi. Fen Bilimleri Enstitüsü, Tarım Ekonomisi Anabilim Dalı. Doktora Tezi. Adana, 2014.

Sanjuán, A. I., Sánchez, M, Gil, I. M, Gracia, A, Soler, F. 2003. Brakes to organic market enlargement in Spain: Consumers' and retailers' Attitudes and Willingness to Pay. International Journal of Consumer Studies, 27: I34144.

Sarıkaya, N. 2007. Organik Ürün Tüketimini Etkileyen Faktörler ve Tutumlar Üzerine Bir Saha Çalıșması. Kocaeli Üniversitesi Sosyal Bilimler Enstitüsü Dergisi,2(14): I I0-125.

T.C. Gıda Tarım ve Hayvancılık Bakanlığı 2016. (www.tarim.gov.tr) (Erișim Tarihi: 28.03.2018)

Tetik, S. 2012. Türk tüketicisinin organik ürün tercih etmesine neden olan faktörlerin uygulamalı olarak incelenmesi. Uluslararası Hakemli Beșeri ve Akademik Bilimler Dergisi Temmuz/Ağustos/Eylül Yaz Dönemi Cilt: I Sayı: I Yıl:20I2 lel Kodu: M ID:07

Torjusen, H, Lieblein, G, Wandel, M, Francis, C. A. $200 \mathrm{I}$. Food System Orientation and Quality Perception Among Consumers and Producers of Organic Food in Hedmark County, Norway. Food Quality and Preference 12: 207-216.

TÜIK 2017. Organik Bitkisel Üretim. (www.tuik.gov.tr) (Erișim Tarihi: 23.3.2018) 
Ustaahmetoğlu E, Toklu Tí 2015. Organik Gıda Satın Alma Niyetinde Tutum, Sağlık Bilinci ve Gıda Güvenliğinin Etkisi Üzerine Bir Araștırma. Ekonomik ve Sosyal Araștırmalar Dergisi, II (I) : 197-2II.
Varoğlu, T.S., Turhan, Ș. 2016. Organik Ürünlerde Tüketici Eğilimlerinin Belirlenmesi Üzerine Bir Araștırma Sakarya İli Örneği. Gaziosmanpașa Üniversitesi Ziraat Fakültesi Dergisi. (2016) 33 (3), 189-196 
